\title{
The Concept of Corruption Prevention Using a Transcendental Approach
}

\author{
Mukhlishin \\ Universitas Muhammadiyah Mataram \\ anakshaleh576@gmail.com
}

DOI: $10.23917 /$ jtl.v2i2.11856

Submission
Track:
Received:
31 July 2020
Final Revision:
21 December 2020
Available online:
29 December 2020
Corresponding
Author:
Mukhlishin
anakshaleh576@gmail.com

\begin{abstract}
Corruption in Indonesia has injured the nation's philosophy of being civilized and divine. From the various measures (laws) that have been implemented, the results have not shown the maximum, instead increasing the number of suspects. Prevention of these crimes is urgently needed by exploring the transcendence value of state law based on Pancasila. This study aims to describe the concept of preventing corruption with a transcendental approach. The method used is a literature review and philosophical approach and descriptive analysis. The result is that the concept of preventing the crime of corruption with a transcendental approach must be based on the divinity concept in the first principle of Pancasila by involving religious doctrine as a legal basis that exceeds moral and spiritual boundaries. Belief in the one and only God in Pancasila can create a solid foundation of trust and a selfsacrificing attitude (integrity), conscious servitude to God, and obedience to leaders, and can create values of civility. Pancasila-based legal transcendence is needed in the prevention of corruption. The state is expected to strengthen the divinity doctrine as the basis for the legal trend for citizens.
\end{abstract}

Keywords: prevention; corruption; transcendental.

\section{INTRODUCTION}

Today's understanding of corruption has risen to be narrower than the broad meaning of the past. There are three terms that clarify the meaning of corruption. First, corruption refers to the 
deterioration of the ethical character of the person/perpetrator loss of moral integrity, or even the depravity of the person/perpetrator. Second, corruption generically describes social service groups, whatever the motive is caused by the deteriorating condition of institutional performance, and third, refers to types of practices such as bribes or rewards for conspiracies. (Priyono, 2018, p. 19).

In line with the characteristics of acts of corruption that have been mentioned, the Indonesian government limits the notion of corruption as an act against the law with the intention of enriching oneself, others, or corruption which results in detrimental to the state or the country's economy as the Definition of Corruption According to Law No. 20 of 2001.

In the context of Indonesia as a religious nation, behavior against the law such as corruption is a serious crime problem that is not only a domestic crime but has become a transnational crime that affects security stability, tarnishing the nation's name in the eyes of the world. Any religion strongly condemns acts of corruption. Actions of corruption are stated as cursed acts against both bribes and bribes (bribery) as well as corruption in dishonesty.

In the last few decades, several surveys have found anomalies in the behavior of criminal acts of corruption in Indonesia as a divinity country. From a survey of 1,520 respondents it was found that in eradicating corruption, the public believed that the government had made many efforts to fight corruption. But the public also believes that the corruption rate in Indonesia is still high. A big question that must be resolved. Factors of religion or religious life do not turn out to be a barrier for someone to commit corruption, even corrupt acts are carried out in budget items that are directly related to the afterlife. In fact, a candidate for a regional head who is clearly corrupt and arrested by the Corruption Eradication Commission can be elected by people in an area known for being religious and winning in the regional head elections (Sucahyo).

A growing number of cases of corruption in Indonesia have raised awareness of the destructive impact of corruption on economic development, although no research has considered the value of the threshold at which corruption stifles economic growth which is very concerning (Alfada, 2019, p. 169). Weak of law enforcement, even hedonistic lifestyles, weak role models from public officials to eradicate corruption, make corruption and other social ills more prevalent. Therefore, with the increasingly sadistic plague as a form of moral degeneration of the nation's children, it is irrational if there are simplifications to blame religious doctrine as a source of moral 
corruption. Although, at the practical level of religion, there are things that need to be evaluated (muhasabah) and awareness of the importance of purification of the soul (tazkiyat al-nafs) as a first step to overhaul the paradigm of corruption crimes (Ramli, 2017, p. 125).

Corruption as a social disease epidemic that spreads systemically requires a preventive model not only based on rational fundamentals through various legislative policies in formulating legislation (Putri, 2019, p. 15), improve professional law enforcement, implementation of the principles of good governance, to involve the use of information technology (Bhattacherjee and Shrivastava, 2016, p. 2), as a model for corruption prevention strategies. However, because the awareness and improvement of national morals based on the Pancasila of Belief in the one and only God as the basis for legal transcendence are still considered very weak so that the effectiveness of prevention is still considered to be failing in its implementation.

The positivistic rationalist concept had failed to solve the problems of human life with law, transcendental thinking is the answer to these global unrest, this is because transcendental law is related to an understanding that places legal science in a wider range beyond the normative limits of rational scientific principles (Absori, 2017, p. 1-5).

In the Indonesian context, the principle of Belief in the one and only God is a guiding principle for the ideals of statehood in the country. The principles built are spiritual and ethical principles inclusively for citizens. Based on the principle Belief in the one and only God, the Indonesian nation actually has a solid moral foundation (Maarif, 2017, p. 213). This is actually the basis of a rule of law with absolute moral dimension (transcendental). In this view, Pancasila as a moral foundation has instilled transdental moral principles based on holy texts (Qur'an hadiths and holy books) which originate from revelation as a driving force for the nation's children to live a state life.

Based on this fact, to understand Pancasila fully and completely, it is absolutely necessary to have a fundamental understanding of the divine concept in Pancasila. Because, apart from being the basis of the state, the fundamental understanding of Pancasila is also a view of the life of the nation, soul, and personality which has been a noble agreement since the establishment of Indonesia. 
The most important essential values in Divinity, besides humanity, unity, people and justice (Gianto, 2019, p. 5). Then the divine essence is the main doctrine of all the essences mentioned. This then has an impact on the paradigm of a nation in carrying out the duties of the nation and state which are based on the divine qualities that are embedded in kindness and civility.

In the context of the criminal act of corruption in this country, it can be assumed that the criminal behavior is the result of the moral degradation of the nation's children because they do not fully adhere to the moral principles in Pancasila of Belief in the one and only God as a basis for legal transcendence. Indonesia as a religious and divine nation should be free from this criminal act of corruption. Not the other way around, corruption is ingrained in the culture of society. Because the way we understand law is still considered wrong, namely that religious doctrine as the basis for legal transcendence has not been able to raise awareness that corruption is a crime against humanity that can bring humiliation to a rule of law.

Therefore, preventing corruption in this context must be started by every citizen by understanding fundamentally the religious doctrine in Pancasila which has implications for a mindset perspective on material that is not excessive (hubbud dunya). Meanwhile, eradicating it can only be done by people who are completely clean of corruption (Ishomuddin, 2018), and understand the essence of Pancasila as the basis of a rule of law. A big question that must be answered by Pancasila country is that what is the concept of preventing corruption with a transcendental approach in Indonesian context? This study aims to provide a description of the concept of corruption prevention through a fundamental understanding of the transcendental value of law in Pancasila.

\section{RESEARCH METHOD}

Medotelogically, this research is library research, where the main source/material is obtained from reading and writing books relating to the study material on transcendental law and corruption. The analysis of the discussion uses a philosophical approach to Pancasila-based transcendental law and corruption cases which are then described descriptively. The basic assumption in this study is that the strategy to prevent corruption is not optimal due to the absence of a standardized concept for preventing corruption with a transcendental approach in Indonesian context. 


\section{DISCUSSION}

\section{Corruption and National Moral Degradation}

In the current era of globalization, Indonesian people are starting to not uphold the essence of the nation's ideology. The morals that are taught have begun to weaken by the influence of foreign cultures that enter Indonesia, so that the character of the nation's children begins to be seen from the nature of egoism and hedonism which prioritizes personal self-interest over common interests, such as cases of enriching oneself through corruption. These conditions cannot be separated from the role of the elites of political parties, the bureaucracy and the private sector, for example, such as 100 citizens controlling 55 percent of the country's wealth in Indonesia. (Habibi, 2018).

The problem of corruption is being carried out by a number of officials and political elites who are religious people. As admitted, the punishments for corruptors in Indonesia are relatively light and do not provide a deterrent effect for the perpetrators. Moreover, we are seen by the world as a religious nation that places the highest foundation on religious morality. This means that moral damage to the religious nation (Indonesia) is the main cause of corruption in the country (Abraham and Pea, 2018, p. 1).

Moral in the context of a godly national life can be interpreted as norms that become guidelines for a person or group in regulating their behavior based on God's rules. This means that a divine country should have good morality as a basis for seeing good and bad actions according to their religious beliefs. When belief in religion has been forgotten, it can be said as one of the characteristics of a nation's moral crisis in the form of rottenness, ugliness, dishonesty, bribery, immorality and deviation from holiness. (Hamsah, 2007, p. 5).

The rise of corruption cases in the country is a reflection that Indonesia's moral has fallen below its lowest point. Corruption affects all people because the funds/state assets taken are only used for the interests of individuals and certain/unilateral groups, not for the benefit of the community and the country. Referring to these moral issues, a rearrangement of tools through reform and transformation is required, to create a sociocultural life of society and governance that 
is law-abiding, clean, quality, efficient, and resilient, includes the biggest one, namely human resources who have faith in Belief in the one and only God fundamentally as mandated by the founders of Indonesia in the past.

The cause of corruption in Jack Bologne's theory says that greed is the initial motivation for corruption, then is followed by opportunities, urgency for needs, and then disclosure or action (Ismatullah and Eriswanto, 2016, p. 138). In other words, the occurrence of corruption is felt to be a result of the deterioration of the integrity factor of a nation. This is because integrity is a unity that includes values of perspective (spiritual), autonomy (mental), social connection and tone (physical) which then becomes a mechanism that makes individuals and collectives trust each other. That integrity is what makes everyone consistent in accordance with subtle and wise values and in accordance with the professional code of ethics. Integrity shows the persistence of attitudes, towards actions and moral values adopted by a person. In the context of corruption crimes, the aspect of integrity can determine the success of preventing corruption. Trust, justice and responsibility based on the concept of divinity and awareness as a religious community can be a reference for the integrity of law enforcers in preventing corruption.

Development and fostering of Human Resources (HR) who comply with the law, and have character, quality and values contained in Pancasila as an important and urgent priority, initiating improvements. In order to improve the morality of the nation, it is important to take a serious preventive action initiated by the moral repentance movement of the nation (Napitupulu, 2019). In order to leave the quality character of social sins by exploring the five principles of Pancasila fundamentally according to the top order, namely Belief in the one and only God which implies the obligation to worship for every religion and an attitude of sacrifice for the benefit of the nation and the internalization of diversity values (morals) in order to restore the dignity of the nation and improve the mental health of the nation from adversity (Deurzen, 2017, p. 2).

In a prophetic perspective, religious obedience is a concept that describes the condition of a person who practices the whole commandments and keeps away from prohibitions (obeying) in the way exemplified by the Prophet. This is then referred to as the concept of tauhid (true deification of God) as the highest moral foundation in exercising rights and obligations in the life of citizens. So, the better the practice of this understanding, the better the quality of one's life. 
Based on this fundamental paradigm, the root of the problem of corruption in the context of a religious nation lies in the damaged understanding and practice of the understanding held by a nation. Islam offers a trilogy concept of religious understanding in the context of the state. The first trilogy is to deify God properly. This concept will bring the human consciousness that life is only serving God. Second, sharia as a way or way of serving God. This is where God's rules must be implemented totally, including the prohibition of doing anarchism, and suppressing the rights of others. This second concept becomes a guideline for positive behavior, as a consequence of this servitude. Then, the third concept is adab or spreading goodness for mankind as an effort to internalize the faith and the sharia. If this fundamental doctrine is embedded in the life of the nation's children in particular, it can be ascertained that the Pancasila law can really prevent criminal acts of corruption.

In a broader perspective, religion is not only synonymous with beliefs and rituals, but it needs to be emphasized in it the aspect of ethical commitment by placing compassion for all humankind and at the same time emphasizing the aspect of morality as the heart of religious life in the context of diversity. The divine values desired by Pancasila - quoting Bung Karno's opinion are cultural and civilized divine values, namely divine ethical values which are extracted from the prophetic values of religions that liberate and glorify justice in the nation and with a spirit. (Dewantara, 2017, p. 11).

Applicatively, in the context of prevention efforts using the approach of religious teachings as the basis for legal mental treaties, efforts to instill national morality based on respective religious beliefs which are fundamentally embraced are priority scales. This is because all religions have agreed that they do not allow corruption (Ristianto, 2019). Hence, the perception of corruption as a serious crime (the enemy of religion) is also a determining factor in overcoming it (Sihombing, 2018 , p. 288). In other words, the perception of the crime is related to the level of success in preventing corruption.

Externally, corruption prevention has probably been carried out by the government through the remuneration program, increasing salaries and allowances, adding facilities and providing training to improve work skills and implementing good governance (Bakhri, 2017, p. 147-148), including demonstrating the anti-corruption slogan (Zhu and Li, 2018, p. 190). At the level of the 
internal aspect, it seems that efforts are needed to form rules and implement laws with a transcendental dimension born from the Pancasila understanding, one of which is the principle of Belief in the one and only God, as an anti-corruption recipe as aspired by the state.

\section{Transcendental Based Corruption Prevention Concept}

Immanuel Khan uses the term transcendental as a process that crosses the boundaries of human experience, so transcendental law means making legal rules that cross the boundaries of experience both in the context of justice, certainty and legal usefulness. For scholastics, transcendental people are understood to be super-categorical, that is, they cover things that are broader than traditional categories, namely form, potential, and action. Transcendental is able to reveal the universal and sensory features of being that are captured through an intuition that transcends experience (Absori, p. 15). This thought then continues to develop and gives rise to the term contemplative law today. Fundamental research explores the philosophy of human nature to spiritual values. Contemplative law examines the most important component in human extension, namely the conscience (fitrah) which cannot be separated from God as the creator. In other words, punishing with contemplation puts the pros and cons and the right or wrong of the law based on conscience as the bearer of the law (Warassih, 2016, p. 10-11).

Transcendental law in the Indonesian context is in accordance with the state ideology embodied in Pancasila. So it is natural that Indonesia is often referred to as a Pancasila country. The essence of Pancasila which is most important in the context of diversity is divinity. This means that every religion that recognizes the existence of God will definitely have a sense of humanity, unity, populism and justice (Absori and Farkhani, 2016, p. 7-9). The manifestation of Pancasila ideology as a protector of law is manifested from its main function as the foundation and direction of the construction and development of national law.

Pancasila is often referred to as the state philosophy and state ideology, which means that in regulating government and state administration it must touch the life of the state which is then used as a legal ideal (staatsidee) which must be carried out consistently in the life of the nation and state. Pancasila is also very full of functions and positions as the principal or fundamental rule of the state or fundamental norms (Asshiddiqie, 2006, p. 22-23). 
Pancasila is then mutually agreed upon as a way of life of the nation and secular as the source of all sources of law. The nation's perspective on life is always based on meta-juridical values, based on mutually agreed upon moral values. With this Pancasila as well, as the basis for the nation's spiritual values taken from religious thoughts based on universal humanism morality (Absori and Farkhani, p. 30).

Divinity in the first Pancasila framework, describes the ethical commitment of the Indonesian nation to carry out a political strategy based on the values of religious morality and noble character (akhlak mahmudah). This definition implies a belief in the existence of God as the creator of the universe and its contents (Yuwita, 2018, p. 78). The same thing is in line with the message in the preamble to the 1945 Constitution, that the Indonesian state is based on Belief in the one and only God according to the basis of just and civilized humanity. The principles of the law contain the contents of the order that state administrators are obliged to maintain noble human character and uphold the moral ideals of every people (Latif, 2015, p. 17).

The concept of divinity as described in Pancasila is a positive attitude that is extracted from the prophetic values of religions that are inclusive, which include belief and sacrifice, conscious servitude to God, loyalty to leaders and being civilized, namely behaving politely in national life and patriotic. This first principle puts the dimension of religion in every aspect of state life (politics), as well as bringing together the symbiosis of the conception of "God's power" with "people's power" which Kontowijoyo described as "theodemocracy." With this principle, collective and individual life initially oriented secular to a more sacred (religious) direction, namely a combination of theocentrism and anthropocentrism.

Theocentric refers to the view that beliefs and values related to divinity are morally superior to other systems. In the perspective of samawi religions (religions that come from revelation/heaven), theocentrism in the first principle of Pancasila implies the concept of centering on God in human creation. In other words, this first Pancasila provides a view to the Indonesian people that the ultimate goal of humans in this world is to serve God and to be accountable for what has been done. In the theocentric perspective, God asks people to follow the law of morality through the awareness to love God absolutely, whole-souledly, with all their strength and mind. 
Theocentric also emphasizes the function of freedom in relation to the role of humans as caliph (manager) of life on earth. Humans are required to live a life that is oriented towards the preservation of life and harmonious relationships with other creatures (including the natural environment). So that one form of conscious servitude to God is a loyal attitude towards the leader. Because it is a command from God as in the holy book of Muslims surah an-Nisa' [4] verse 59: “...obey Allah and obey the Messenger and those in authority among you..." as a moral foundation to behave in a state government system. That is, the theocentrism foundation produces loyalty to the leader. In a leadership system whether in the form of self-leadership or an institution, individuals are required to obey God, because being loyal to the creator, someone will think of committing the crime of corruption.

Meanwhile, the anthropocentric combination in Pancasila is a paradigm about humans as the center of the universal system. Humans when they become the center of the universal system must have the awareness not to exploit the rights of other humans (being greedy). The anthropocentrism paradigm teaches humans not to overdo it, because nature can only be managed for the sake of the happiness of many people. Finally, back to the source of human control. Humans who are aware of the divinity value in themselves, will have a tendency to spread rahmatan lil 'alamin (compassion for all nature). This kind of nation even views differences as a blessing. Pluralism in the context of religion is internalized by the values of civility. Pancasila in this case can be the foundation stone of a humanist civilization (Sitorus, 2016, p. 700), for stakeholders in the Indonesian.

The issue of preventing corruption in Indonesia is urgently needed for humanitarian reasons which are very immoral. The entrance to corrupt behavior can occur because if there is motivation/encouragement from employees to misuse money and institutional assets (intention), it is driven by circumstances and mindset and ethics (Kassem and Higson, 2012, p. 190). In this regard, corruption can be prevented by understanding the original intention of the perpetrator. This is where the fundamental teachings of religion (tauhid) are needed as a philosophy of life, especially for Indonesian citizens who are found in Pancasila. In other words, before prevention is technically like Greyclar and Prenzler concepts by making it difficult to commit corruption, reduce the causes that tolerate/allow corruption to occur, increase the risk of detection, reduce incentives 
for corruption, and reduce provocation for corruption (Graycar and Prenzler team, 2013, pgs. 7273), the nation's moral order must be built by taking into account the divinity philosophy as the basis for a religious state.

Based on the description above, transcendental law based on Pancasila must be a source of values for preventing corruption crimes in Indonesia. Corruption often occurs when there is an intention and opportunity by the perpetrators which is sometimes done deliberately, collectively and in an organized manner (Sabani, Farah, and Dewi, 2019), Therefore, the key to realizing a devine nation of law is to make Pancasila values and religious norms the transcendental principles of law. Its relation with Pancasila is to ignore the divinity aspect in oneself (conscience) which results in and has the potential to violate the following precepts including social justice for all Indonesian people because it undermines the wealth of the country, which in the end is detrimental to the state and also the people.

Based on the paradigm of divine doctrine in religion, concrete efforts that can be made to optimize the notion of divinity Pancasila as a concept to prevent corruption, require an intensive understanding of religious teachings for all state officials who hold sensitive authorities in state institutions. Religious spiritual training efforts can be realized by continuously and fundamentally inculcating divinity values in each religion.

In a broader context, the government needs to strengthen anti-corruption education that emphasizes aspects of the principles of religious basics and the internalization of the values of Belief in the one and only God in organizational life for public officials in the country. In the internal context of education, in the sense that the implementation of anti-corruption education starts from independence and commitment of stakeholders, for example not being late for absence, enforcing strict penalties for corrupted administrative staff and faculty; introducing an active student attendance control system (Feoktistova, 2013). This is a tangible form that the implementation of the principle of Belief in the one and only God is not rigid as a meaningless concept, because this principle should be multi-dimensional, both formal (educational and state institutions), the surrounding environment (non-formal). and family (informal) framed with religious spirit. 


\section{CONCLUSION}

Departing from some of the descriptions in this study, it can be concluded that the trandency legal approach in Pancasila - especially the first principle - is indispensable for every lawmaker as an optimal effort to prevent corruption crimes that have an Indonesian aroma. This is important to do because the damaged understanding and practice of the divinity adopted by the community is the main cause of corrupt behavior in the country, therefore it is very important that transcendental legal approach is based on state ideology, namely Pancasila as the basis for enforcing a law that crosses moral and spiritual values according to religious beliefs in Indonesia. The concept of preventing corruption with a transcendental approach can be concrete in the form of intensive religious concept through a forum such as anti-corruption education that has been organized by the government which is mandatory for all public officials and the public to instill the transdental values of Pancasila in Divinity as a servant (loyal) to God consciously and obedience to leaders, as well as awareness as a civilized nation.

\section{REFERENCES}

Abraham, Juneman, and Pea, A. G. "Can Proneness to Moral Emotions Detect Corruption? The Mediating Role of Ethical Judgment Based on Unified Ethics." Kasetsart Journal of Social Sciences (2018): 4-11. https://doi.org/10.1016/j.kjss.2018.07.013.

Absori, A. "Pemikiran Hukum Transendental Dalam Konteks Pengembangan Ilmu Hukum Indonesia" (2017).

Absori, and Farkhani. Cita Hukum Pancasila: Ragam Paradigma Hukum Berkeperibadian Pancasila. Surakarta: Pustaka Iltizam, 2016.

Alfada, A. "The Destructive Effect of Corruption on Economic Growth in Indonesia: A Threshold Model." Heliyon 5, no. 10 (2019): e02649. https://doi.org/10.1016/j.heliyon.2019.e02649.

Asshiddiqie, J. "Ideologi, Pancasila Dan Konstitusi." Jaringan Informasi Hukum, no. 1 (2006): $1-23$.

Bakhri, S. "Pencegahan Tindak Pidana Korupsi Di Indonesia Era Otonomi Daerah Malalui Prinsip Goog Goverment." Al-Qist 1, no. 2 (2017): 130-148.

Bhattacherjee, Anol, and Shrivastava, U. "The e Ff Ects of ICT Use and ICT Laws on Corruption : A General Deterrence Theory Perspective," no. July 2016 (2018): 1-10.

Van Deurzen, I. "And Justice for All: Examining Corruption as a Contextual Source of Mental Illness." Social Science and Medicine 173 (2017): 26-34. http://dx.doi.org/10.1016/j.socscimed.2016.11.033.

Dewantara, A. W. Diskursus Filsafat Pancasila Dewasa Ini. Yogyakarta: PT Kanisius, 2017.

Feoktistova, Y. "Corruption in Higher Education and Government Measures for Its Prevention." 
Procedia - Social and Behavioral Sciences 112, no. Iceepsy 2013 (2014): 167-172.

http://dx.doi.org/10.1016/j.sbspro.2014.01.1152.

Gianto. Pendidikan Filsafat Pancasila Dan Kewarganegaraan. Ponorogo: Uwais Inspirasi Indonesia, 2019.

Graycar, Adam, and Tim Prenzler. Understanding and Preventing Corruption. Springer, 2013.

Habibi. "Krisis Moral Dan Etika Bangsa Indonesia Masih Sulit Dikendalikan | Universitas Muhammadiyah Yogyakarta.” BHP UMY. Last modified 2018. Accessed October 17, 2019. http://www.umy.ac.id/krisis-moral-dan-etika-bangsa-indonesia-masih-sulitdikendalikan.html.

Ishomuddin, A. "Melawan Korupsi Di Negeri Kaum Beragama." Bangkitmedia.Com. Last modified 2018. Accessed October 19, 2019. https://bangkitmedia.com/melawan-korupsi-dinegeri-kaum-beragama/.

Ismatullah, Ismet, and Eriswanto, E. "Analisa Pengaruh Teori Gone Fraud Terhadap Academic Fraud Di Universitas Muhammadiyah Sukabumi." Riset Akuntansi dan Keuangan Indonesia 1, no. 2 (2016): 134-142.

Hamsah, J. A. Pemberantasan Korupsi Melalui Hukum Pidana Nasional Dan Internasional. Jakarta: PT RajaGrafindo Persada, 2007.

Kassem, Rasha, and Higson, A. "The New Fraud Triangle Model." Journal of emerging trends in economics and management sciences 3, no. 3 (2012): 191-195.

Napitupulu, M. “Gerakan Moral Untuk Mencegah Korupsi.” Koran Sindo. Last modified 2019. Accessed October 17, 2019. https://nasional.sindonews.com/read/1419883/18/gerakanmoral-untuk-mencegah-korupsi-1562961727.

Maarif, A. S. Islam Dan Pancasila Sebagai Dasar Negara. Bandung: PT. Mizan Pustaka, 2017. Priyono, B. H. Korupsi: Melacak Arti, Menyimak Implikasi. Jakarta: Gramedia Pustaka, 2018.

Ristianto, C. "Menag: Semua Agama Melarang Umatnya Korupsi." Kompas. Com. Last modified 2019. Accessed October 19, 2019.

https://nasional.kompas.com/read/2019/02/07/17443571/menag-semua-agama-melarangumatnya-korupsi.

Sabani, Alvedi, Mohamed H. Farah, and Dian Retno Sari Dewi. "Indonesia in the Spotlight: Combating Corruption through ICT Enabled Governance." Procedia Computer Science 161 (2019): 324-332. https://doi.org/10.1016/j.procs.2019.11.130.

Sihombing, Sabrina O. "Youth Perceptions toward Corruption and Integrity: Indonesian Context." Kasetsart Journal of Social Sciences 39, no. 2 (2018): 299-304. https://doi.org/10.1016/j.kjss.2018.03.004.

Sitorus, Jordan Hotman Ekklesia. "Pancasila-Based Social Responsibility Accounting." Procedia - Social and Behavioral Sciences 219 (2016): 700-709.

Sucahyo, Nurhadi. "Aneh, Masyarakat Religius Namun Korupsi Tinggi.” Oaindonesia.Com.

Supian Ramli. "Maqâmât Tasawuf Dan Terapi Anti Korupsi (Studi Alternatif Pemberantasan Korupsi Di Indonesia)." Jurnal Studi Al-Qur'an 13, no. 02 (2017): 187-2015.

Warassih, Esmi. "Ilmu Hukum Yang Kontemplatif." Dalam Penelitian Hukum Interdisipliner, Sebuah Pengantar Menuju Sosio-Legal (hal. 10-11). Yogyakarta: Thafa Media (2016).

Wiki Oktama Putri. "Penegakan Hukum Terhadap Anggota Legislatif Dalam Kasus Tindak Pidana Korupsi Di Indonesia.” ad-daulah 8, no. 1 (2019): 1-15. 
Yudi Latif. Negara Paripurna: Historisitas, Rasionalitas, Dan Aktualitas Pancasila. Jakarta: Gramedia Pustaka Utama, 2015.

Yuwita, Nurma. "Pancasila Dalam Konstruksi Pemikiran Teologi Pesantren Dengan Pendekatan Model CMM." Interaksi: Jurnal Ilmu Komunikasi 7, no. 2 (2018): 70-78.

Zhu, Meihong, and Aihua Li. "How the Media Coverage Affects Chinese Publics' Anticorruption Perceptions: Empirical Study Based on Interaction Effect Analysis." Procedia Computer Science 139 (2018): 190-198. https://doi.org/10.1016/j.procs.2018.10.241. 